\title{
LOWER PLATE GEOMETRY CONTROLLING THE DEVELOPMENT OF A THRUST-TOP BASIN: THE TECTONO-SEDIMENTARY EVOLUTION OF THE OFANTO BASIN (SOUTHERN APENNINES) \\ EVOLUTION OF THE OFANTO THRUST-TOP BASIN
}

Casciello Emilio* - Group of Dynamics of the Lithosphere (GDL), Institute of Earth Sciences "Jaume Almera", CSIC, Lluís Solé i Sabarís s/n, 08028 Barcelona, Spain. ecasciello@ictja.csic.es

Esestime Paolo - Group of Dynamics of the Lithosphere (GDL), Institute of Earth Sciences "Jaume Almera", CSIC, Lluís Solé i Sabarís s/n, 08028 Barcelona, Spain. paoloesestime@yahoo.it

Cesarano Massimo - Department of Biosciences and Territory (DiBT), University of Molise, C.da Fonte Lappone, 86090, Pesche (IS), Italy. cesarano@unimol.it

Pappone Gerardo - Department of Sciences for the Environment, University of Naples Parthenope, Centro Direzionale Isola C/4, 80143 Napoli, Italy. gerardo.pappone@uniparthenope.it

Snidero Marco - Geomodels Research Institute, GGAC, Dept. Geodinàmica i Geofísica, Facultat de Geologia, Universitat de Barcelona. 08028 Barcelona, Spain.msnidero@ub.edu

Vergés Jaume - Group of Dynamics of the Lithosphere (GDL), Institute of Earth Sciences "Jaume Almera", CSIC, Lluís Solé i Sabarís s/n, 08028 Barcelona, Spain. jverges@ictja.csic.es

Key-words: Southern Apennines, thrust-top basin, Pliocene-Pleistocene, buttressing, flexural normal faults. 


\section{Abstract:}

The Ofanto basin is a Pliocene-Pleistocene thrust-top basin that formed with an unusual E-W orientation along the frontal part of the Southern Apennine Allochthonous (SAA) during the latest stages of tectonic transport. Its tectonic and sedimentary evolution was studied integrating field surveys, biostratigraphic analyses and the interpretation of a large seismic grid. Well data and seismic interpretation indicate that a large E-W trending normal fault underlies the northern margin of the basin, displacing the Apulian carbonates that form the foreland and the footwall of the SAA. In our reconstruction the Ofanto basin formed at the rear of the bulge caused by buttressing of the SAA against this normal fault. In a second stage of contraction, the footwall of the SAA was involved in deformation with a different trend from normal faulting and buttressing. This caused eastward tilting of the basin and broad folding around its eastern termination. Good stratigraphic constrains permit defining as Early Pliocene the age of buttressing, and as Early Pleistocene the shortening in the Apulian carbonates. This work highlights the importance of early-orogenic normal faults in conditioning the evolution of the frontal parts of orogenic wedges.

Supplementary material: A 3D reconstruction of the base of the Pliocene deposits of the Ofanto basin, based on seismic interpretation, is available at www.geolsoc.org.uk/SUP--------. 
61 The Southern Apennines of Italy are a relatively young orogenic belt that formed during the Neogene-Quaternary subduction of oceanic domains of the Neo-Tethys along the southern margin of the Alpine suture (Golonka 2004; Edwards \& Grasemann 2009; Schettino \& Turco 2010). During subduction, the original paleogeographic domains of the Neo-Thetys - Adria region were piled up, forming the Southern Apennine Allochthonous (i.e. Calabrian p.p., Sicilides, Apennine carbonate platform and Lagonegro basinal units), and eastwards thrusted over the Apulia carbonate platform that forms the easternmost domain of Adria (Fig. 1) (Mostardini \& Merlini 1986; Casero et al. 1988; Finetti et al. 2005; Vezzani et al 2010). In the last $7 \mathrm{Ma}$, the leading edge of the Southern Apennines Allochthonous (SAA) migrated hundreds of kilometres toward the east (Scrocca et al. 2005; Edwards \& Grasemann 2009) and was accompanied by the opening of the Tyrrhenian back-arc basin on its hinterland side. Both processes are thought to be driven by the roll-back of the subducting Neo-Thetyan (Ionian) oceanic lithosphere (Malinverno \& Ryan 1986; Kastens et al. 1988; Doglioni 1995). Coeval to the migration of the SAA, Pliocene marine sediments deposited over the translating thrust sheets and recorded in their sedimentary evolution the deformation of the underlying thrust sheets as they emplaced over the Apulian foreland (Bonardi et al 2009; Vezzani et al. 2010). Pliocene thrust-top deposits are distributed over wide areas of the north-eastern part of the Southern Apennines, with the Ofanto synclinorium forming one of the largest outcrops (Fig 1). The study of these basins provides information on the interactions between the advancing frontal thrust sheets and the flexured Apulian foreland (Fig. 2), which is known to be affected by different processes such as bending, buckling and normal faulting 
(Sella et al. 1990; Doglioni 1994; Mariotti \& Doglioni 2000; Bertotti et al. 2001; Billi \& Salvini 2003; Butler 2009).

The E-W trend of the Ofanto synclinorium represents an anomaly in the regional NW-SE structural trend of the Southern Apennines (Vezzani et al. 2010). Different hypotheses have been proposed to explain this anomaly. According to Ortolani (1974) major blind strike-slip faults oriented SW-NE underlie the eastern and western ends of the Ofanto basin and distort with left-lateral movement the NWSE oriented regional folds of this portion of the Apennines. Alternatively, Hyppolite et al. (1994) proposed that the Ofanto basin formed in its present orientation, following to the development of E-W oriented ramp-flat-ramp system in the units underlying the Southern Apennine Allochthonous, in Early-Mid Pliocene times. In addition, Hyppolite et al. (1994) point out that evidence for extensional tectonics is lacking in the basin fill deposits and the sparse extensional faults measured in the basin are related to sediment compaction. On the contrary Patacca and Scandone (2007), based on seismic interpretation propose the existence of large normal faults defining the northern margin of the Ofanto basin, which acted during the deposition of the younger part of the basin fill (post 2.5 Ma, Late Pliocene).

The present paper integrates geological and biostratigraphic studies of the synorogenic Ofanto basin with the interpretation of about $300 \mathrm{~km}$ of reflection seismic lines and well data to define: a) the tectonic geometry of the region underlying and surrounding the Ofanto basin; b) the age of basin formation and its syntectonic deformation, based on new biostratigraphic results; c) the interactions between frontal thrust sheets and the Apulia foreland region affected by the rollback process, and d) the contribution of this study into the larger scale understanding the Southern Apennine compressive belt. 


\section{GEOLOGICAL SETTING}

112 The present-day Ofanto basin is a wide E-W trending synclinorium, about $30 \mathrm{~km}$

113 in length, located in the axial zone of the chain immediately north of the Picentini

114 Mts / Marzano Mt carbonate relieves (Fig. 1). The substratum of this Pliocene

115 basin is formed mainly by Mesozoic to Miocene pelagic units of the SAA, with

116 overlying Late Miocene siliciclastic deposits of the Castelvetere flysch (Fig. 3).

117 The main structural elements exposed at surface, affecting both the Allochthonous

118 thrust sheets and to a smaller extent the Pliocene deposits, are represented by

119 folds and thrusts oriented E-W to WNW-ESE, becoming NW-SE around the

120 easternmost portion of the Ofanto basin (Fig. 3). Large segments of the southern

121 and northern margins of the basin are characterised by thrusts and backthrusts,

122 respectively, which bring the pre-Pliocene substratum over the basin-fill deposits.

123 In some cases, these faults are sutured by younger deposits of the basin.

124 At the eastern end of the basin is the Mid-Late Pleistocene Vulture Volcano (0.67-

$1250.13 \mathrm{Ma}$, Bonadonna et al. 1998). The products of this volcano, which are

126 considered of 'orogenic' magmatism (i.e. subduction-related, Lustrino et al. 2011),

127 cover the Pliocene deposits of the Ofanto basin and record WNW-ESE, left-lateral

128 strike slip deformation, which constitute the latest contractional tectonic events of

129 the Apennines (Schiattarella et al. 2005). The carbonate reliefs to the south and

130 south-west of the Ofanto basin (Fig. 3) are part of the Triassic to Miocene

131 Apennine carbonate platform (Casciello et al. 2006a), which was incorporated into

132 the SAA in Early-Mid Miocene times (Vezzani et al. 2010). The age of thrusting of

133 the SAA over the Apulian Carbonate Platform underlying at depth the Ofanto

134 basin (Fig.2) is constrained by well data indicating a post Early Pliocene age for 
135 the regional-scale superposition (Fig. 4). The direction of tectonic transport of the 136 SAA is not known directly in the study area, however structural data from tectonic 137 windows in the Picentini Mts. indicate an approximately northwards direction of shortening (Pappone \& Ferranti 1995; Casciello et al. 2006b; Pappone et al. 2009). During the Pliocene-Quaternary, the Apulian carbonate platform itself was deformed and reverse faults breached the basal thrust of the SAA (Boccaletti \& Guazzone 1974; Cello \& Mazzoli 1999). Tectonic underplating of Apulian carbonates gave rise to a largely buried thrust belt (Apulian belt, in Cello et al. 1989) that developed in an inner position with respect to the leading edge of SAA, originating an orogen-scale duplex geometry (Fig. 2) (Mostardini \& Merlini 1986; Cello \& Mazzoli 1999). Remarkably, the buried Apulian belt in map view is shaped as a sequence of minor arcs of $100 \mathrm{~km}$ scale order, aligned in a NW-SE direction (Casero et al. 1988; Nicolai \& Gambini 2007; Esestime 2009; Vezzani et al. 2010), which represent the main target in oil exploration. The deposits of the Ofanto thrust-top basin are coeval to the final stages of migration of the SAA and to the later deformation of the Apulian carbonates.

\section{THE OFANTO BASIN INFILL}

The filling of the Ofanto syncline is composed by regressive Pliocene deposits of the Ariano Unit resting unconformably on the pre-Pliocene substratum (Ippolito et al. 1973; D'Argenio et al. 1975). Marine marly clays in the lower part of this unit are followed by coastal and alluvial sands and conglomerates towards the top. Remarkably, conglomerate bodies that were thought to represent the closure term of the basin fill (D'Argenio et al. 1975) are only present along the northern and eastern margins of the basin, further away from the topographically-elevated axial 
part of the chain. Biostratigraphic data on calcareous nannoplankton indicate that the western and central parts of the Ofanto syncline are filled by Early Pliocene deposits (NN15, NN16 Zones) while the eastern part of the basin is younger, exposing Late Pliocene deposits (NN18 Zone; Gelasian) (Hyppolite et al., 1994; Bonardi et al. 2009; Giannandrea et al. 2009; Ascione et al. 2011). A modern statigraphic analysis of the basin fill is available only for the eastern half of the basin (Giannandrea et al. 2009) where six unconformity-bounded units were defined, comprising marine to continental deposits of Pliocene to Early Pleistocene age.

In order to integrate and homogenize stratigraphic information for the entire basin10 stratigraphic sections were sampled for analyses on planktonic foraminifera and field surveys were made throughout the basin. Biostratigraphic dating was aimed primarily at defining the age of conglomerate bodies along the basin's northern margin that can be used as markers for relative sea-level changes (Palladino et al. 2011). Sites of sampling and results of biostratigraphic analyses are shown in figure 3 . The main outcome of this study is the recognition of three generations of conglomerates, spanning in age from Early Pliocene to Early Pleistocene and characterised by an approximately centrifugal distribution with respect to the E-W trend of the Ofanto syncline (Fig. 5).

The oldest conglomerates are fan-delta deposits exposed in the area of the Andretta village (Fig. 3). These conglomerates rest directly over the pre-Pliocene substratum and are stratigraphically overlain by transgressive marly-silty clays containing G. puncticulata (MPL4a - Early Pliocene). The Andretta basal conglomerate displays a clear southwards dip evidenced by a $15^{\circ}$ tilted lacustrine interval comprised between coarse conglomerate beds (Casciello \& Cesarano, 
2000). Retrogradational fan-delta conglomerates that correlate to the Andretta deposits are distributed over large areas of the Southern Apennines (Ciarcia et al. 2003; Palladino et al. 2011; Fig. 1) documenting a generalized subsidence during the late Early Pliocene (Ascione et al. 2011).

The second generation of conglomerates in the basin infill is found in the central part of the Ofanto syncline, creating high topographic relief around the Cairano and Calitri villages (Fig. 3). This younger generation of deltaic conglomerate bodies rest above the G. puncticulata marly clays and displays erosional basal contact marked by a slight angular unconformity. The observed exposures of basal strata around the Cairano village are characterised by decimetre-scale clay clasts composed by the same G. puncticulata mudstones that form the conglomerate substratum, indicating strong erosion of the source area.

Paleocurrent observations from imbricate clasts and sole marks at the base of arenaceous beds indicate a sediment supply mostly from the north.

The third and youngest generation of conglomerate is found around the eastern and western extremes of the Ofanto syncline. Planktonic associations containing G. inflata (MPL6 - latest Pliocene) were found in samples extracted from mudstones immediately underlying these conglomerates (Fig. 3) suggesting a Late Pliocene-Early Pleistocene age for the overlying rudite. While for the eastern conglomerates (i.e. Toppo Pescione) these results confirm calcareous nannoplankton datings provided by Hyppolite et al. (1994), and confirmed by Ascione et al. (2011) the western conglomerate exposures around the Guardia Lombardi village result younger than previously dated. 
In the eastern half of the basin a detailed stratigraphic analysis was performed by

Giannandrea et al. (2009), resulting in the definition of six unconformity-bounded

units encompassing the entire basin fill. This interpretation is used here to complement the stratigraphic framework of the Ofanto basin, with a special emphasis on the Late Pliocene deposits.

Comparison between the unconformity-bounded units of Giannandrea et al.

216 (2009) and the subdivision adopted in the present study (Fig. 5) indicates overall correspondence, except for the youngest deposits, where a more detailed subdivision is proposed by Giannandrea et al. (2009). Within the third generation of conglomerates overlying the $G$. inflata mudstones, these authors differentiate two conglomerate bodies separated by an erosional angular unconformity. The the Mid Pleistocene volcanic products of Mt. Vulture are present. 


\section{SEISMIC INTERPRETATION}

235 The subsurface structural setting of the Ofanto basin was investigated using borehole data and the interpretation of a 2D seismic grid with a total length of approximately $300 \mathrm{~km}$ (Fig. 4). The primary objective of this analysis is to define the geometry of two key surfaces: 1) the base of the Pliocene infill of the Ofanto basin, and 2) the top of the Apulian Carbonate Platform.

The reconstruction of the base of the Ofanto basin was carried out transferring the exposed boundaries of the base of the Pliocene, reported by 1:100.000 scale geological maps, along the seismic sections. Seismic interpretation of the base of the Pliocene succession was facilitated by its well-layered seismic facies contrasting with the noisy signal containing interspersed anonymous horizons, which characterises the underlying Southern Apennine Allochthonous units. The complexity of these latter thrust units is due to their composite nature, comprising deepwater successions of the Lagonegro basin and Miocene siliciclastics of older foreland and thrust top settings (Pescatore, 1988; Vezzani et al. 2010), and to their poly-deformed history with remarkable shortening (e.g. Pappone \& Ferranti, 1995; Mazzoli et al., 2001). Seismic interpretation in this structural level was aimed essentially at the identification of structures that affect the overlying Pliocene deposits.

For the reconstruction of the top Apulian surface the Monte Forcuso1-2 and the Ciccone1 wells were used to calibrate the top of the carbonate platform (Fig. 4). Picking of top Apulian horizons started from calibrated lines, extending progressively across intersecting-points of the grids, guided also by the recognition of the high amplitude low frequency double event that characterises the seismic signal of the top Apulian surface (Shiner et al. 2004; Nicolai \& 
259 Gambini 2007). The poor quality of seismic signals at the top of the Apulian 260 Platform does not permit a univocal interpretation of individual fault planes.

261 Therefore, in this structural level the picking of horizons and the mapping were focused preferentially on the reconstruction of the structural relief of the top Apulian horizon.

The results of this analysis of seismic data are illustrated by 5 line drawings of seismic sections traversing the Ofanto syncline in a SW-NE direction (Figs. 6, 7) and by a 3D model constructed in CAD environment using all the available data (Fig. 8).

\section{SHALLOW STRUCTURE OF THE OFANTO BASIN}

The Pliocene filling of the Ofanto basin is clearly imaged in the seismic sections, being characterized by strong and continuous reflectors. The five parallel line drawings of figure 6 illustrate a progressive deepening of the basin from west to east, which is in agreement with the eastwards younging of the deposits exposed at surface (Fig. 3). However, despite the eastward deepening the plan-width of the basin remains fairly constant along its axis (E-W direction), displaying an average $\mathrm{N}-\mathrm{S}$ width of 7-10 km. All the studied seismic sections show an overall asymmetry of the basin's profile with the northern margin more steeply inclined than the southern one. Except for line A, which traverses the basin in its western termination and presents a lower quality, all studied sections show that the base of the Pliocene basin is involved in thrust deformation. The southern and northern margins are deformed by north-verging thrusts and by south-verging back-thrusts, respectively, that have also been recognised in field-based studies (Fig. 3) (Casciello \& Cesarano, 2000; Giannandrea et al. 2009). Along the southern 
margin, the activity of these thrusts produces shallow marginal depocentres connected to the main basin (Fig. 6B-C). On the opposite side, back-thrusts affecting the northern shoulder of the basin are more evident showing larger apparent displacements and contributing to the steeper conformation of the basin's northern margin.

Deformation during Pliocene deposition is documented also by angular unconformities in the basin fill and by the shifting of depocentres through time. In lines B, D of figure 6 depocentres are located in the northern side of the basin and appear to progressively migrate southwards, as noted by Hippolyte et al. (1994), in response to the uplift of the northern shoulder of the basin. Uplift of the northern margin also correlates well with evidence of strong erosion of the Early Pliocene
G. puncticulata mudstones along the northern margin and its re-deposition as clay clasts in the second generation of conglomerates (Fig. 5), as observed in the area of Cairano village. Section D displays an approximately homogeneous southwards growth of the basin; on the contrary, the easternmost section (line E in Fig. 6) presents a more complex architecture, with packages of reflectors that diverge alternatively to the south and to the north and the younger part of the section, up to the Late Pliocene-?Pleistocene conglomerate, dipping homogeneously to the NE. This late-stage north-eastwards tilt of the basin fill was suggested to be related to the growth of an antiformal stack within the Lagonegro allochthonous units (S. Fele antiformal stack) causing also the thickening of the Southern Apennine Allochthonous in this area (Hippolyte et al., 1994; Patacca \& Scandone, 2007).

DEEP STRUCTURE OF THE OFANTO BASIN 
309 The deep structural elements of the studied area are formed by the Apulian

310 Platform Unit, which lies below the Southern Apennine Allochthonous and 311 represents the lowermost tectonic unit of the Southern Apennines (Fig. 2). At a 312 regional scale, well data indicate that the top of the Apulian carbonate platform is 313 a diachronous level varying in age from Early Cretaceous (Acerno 1 well) to 314 Miocene (Melfi1, Lavello 4-5; Fig. 4). This surface is locally covered by Messinian 315 evaporites and by siliciclastic intervals spanning in age from Early Pliocene to 316 of the top Apulian Platform suggests a structural and morphological relieve prior to burial by the migrating Allochthonous units. This is in agreement with seismic and field evidence of major normal faults, both pre-orogenic (Mesozoic) and synpresent below the northern margin of the Ofanto syncline (Fig. 7). The M. Forcuso 1 and the Ciccone 1 wells (Fig. 4) are drilled in the footwall and hangingwall of this normal fault and intercept the top of the Apulian Platform at depths of $1100 \mathrm{~m}$ and footwall block.

The fault-throw of the normal fault is confirmed in all sections along the studied 
towards the south (Fig. 7). The fault displacement does not propagate up-dip into the Allochthonous, presenting a fault-tip at the level of its basal thrust, indicating that normal fault activity occurred prior to its emplacement. The basal thrust surface of the Allochthonous units displays smooth trajectories across the step produced by the normal fault, manifested by inclined reflectors connecting points of the top Apulia platform in the hangingwall to the footwall cut-off (Fig. 6).

A different set of structures involving the Apulian carbonates is represented by reverse/thrust faults, and associated folds, which displace the basal thrust of the Allochthonous. These contractional structures are thus posterior to the emplacement of the SAA thrust sheets. The overall trend of these thrusts in the Apulian carbonate platform is NW-SE, with branches that display NNW-SSE orientation and local arched geometries (Fig. 7). Due to their different trends the contractional structures cross-cut and displace the normal fault (Fig. 8), so that its eastern part is uplifted in the thrust's hangingwall (Fig. 6A) while the western part of the normal fault remains in the footwall of the contractional structure (Fig. 6B, C, D, E,). Thrust imbricates within the Apulian carbonate platform and the associated ramp anticlines result in an overall structural uplift of the top Apulian surface by 1.2-1.8 seconds twt with respect to the footwall (Fig. 7).

\section{DISCUSSION}

The most evident structural elements exposed at surface are represented by folds and thrusts oriented E-W to WNW-ESE, becoming NW -SE around the easternmost portion of the Ofanto basin (Fig. 3). These orientations are in agreement with paleostress reconstructions provided by Hyppolite et al. (1994), which indicate three main directions of maximum compression: $\mathrm{N} 170^{\circ}$ (i.e. $\mathrm{N}$ 
$350^{\circ}$ ) and $\mathrm{N} 25^{\circ}$ during the Pliocene, and $\mathrm{N} 70^{\circ}$ in Early Pleistocene. However, when comparing the orientation of surficial structures (Fig. 3) to the trend of contractional faults in the buried Apulian carbonates (Fig. 7) a noticeable mismatch becomes apparent. Thrusts affecting the Apulian platform are in fact oriented predominantly NW-SE, agreeing in orientation only to the latest contractional event, Pleistocene in age, identified by Hyppolite et al. (1994). E-W trending surficial structures, however, correspond to the orientation of the normal fault in the Apulian carbonates (Fig. 7), which forms a structural step with 1 $\mathrm{km}$ throw just below the northern margin of the Ofanto basin. Seismic interpretation indicates that this normal fault pre-dates the emplacement of the Southern Apennines Allochthonous (i.e. the fault does not propagate across the basal thrust of the SAA). Therefore it seems reasonable to suggest that the escarpment of this large normal fault played a significant role during the emplacement of the Allochthonous. In this scenario the approximately E-W trending thrusts and back-thrusts that bound the Ofanto syncline to the south and to the north can be interpreted as accommodation structures related to the buttressing of the Southern Apennines Allochthonous against this structural step during its translation towards the foreland (Fig. 9). The resulting structural setting, characterized by thrust systems with opposing senses of vergence resting on a common detachment surface (Fig. 6), may be assimilated to a large triangle zone (Erickson, 1995; Couzens-Shultz et al., 2003) with the Ofanto syncline located at the apex of the triangle. The timing of this main phase of Allochthonous translation and buttressing is comprised between the lowermost Pliocene age of the underthrusted deposits containing Sphaerodinellopsis (Ciccone 1 well in Fig. 4; stage A in Fig. 9), and the uppermost Early Pliocene age of the G. puncticulata 
mudstones involved in buttressing-related thrust deformation (stage C in Fig. 9). It is worth highlighting that the youngest generation of conglomerate (i.e. Toppo Pescione and Guardia Lombardi in Fig. 5) of Late Pliocene-?Early Pleistocene age, does not show E-W trending, buttressing-related structures.

In a later phase of shortening, the Apulian carbonates in the footwall of the SAA became involved in contractional deformation and regional NW-SE trending reverse faults (Fig. 7) developed, cutting through the basal thrust of the Allochthonous units (stage E in Fig. 9). These NW-SE trending Apulian thrusts, corresponding to the frontal structures of the Buried Apulian Belt (Casero et al. 1988; Cello et al. 1989; Esestime, 2009), generate an eastward slope in the top Apulian carbonates that compose the hangingwall of the normal fault (Fig. 8). This eastward tilt of the top Apulian carbonates is mirrored at shallower depth by a corresponding eastward deepening of the base of the Ofanto basin (Fig. 3 and 3D model of the base of the Pliocene, in supplementary material). We therefore propose that the overall eastward axial plunge of the Ofanto syncline is related to the deep structuring of the Apulian carbonates.

The age of north-eastwards thrusting in the Apulian platform, and consequently of the eastwards tilt of the Ofanto syncline, is certainly posterior to the main phase of Allochthonous translation and buttressing (Early Pliocene), and may correspond to the age of formation of the large open syncline oriented NW-SE, found in the eastern termination of the Ofanto basin (Fig. 3). This syncline deforms the third and youngest generation of conglomerates (Toppo Pescione), which overlie the G. inflata mudstones (Fig. 5) and is therefore almost certainly of Pleistocene age. The youngest contractional structures in the studied area are represented by WNW-ESE left-lateral strike slip faults that deform volcanic deposits of Mt. Vulture 
and are sealed by younger volcanic products ( $484 \pm 8 \mathrm{ka}$; Schiattarella et al. 2005). Based on kinematic compatibility with north-eastwards shortening in the Apulian carbonates, we consider this youngest contractional deformation (up to mid-Pleistocene in age) as a late-stage expression of NE directed tectonic shortening.

\section{COMPARISON WITH OTHER PLIO-PLEISTOCENE BASINS OF THE} SOUTHERN APENNINES

Immediately to the north and to the east of the study area, other thrust-top deposits are present that are time equivalent to those analysed in the Ofanto basin (Fig. 1). Correlation with the deposits exposed around the Ariano Irpino area (Ciarcia et al. 2003; Di Nocera et al. 2006) and in the Acerenza area (Palladino et al. 2011) permits integrating the tectono-sedimentary evolution of the Ofanto basin into a more regional perspective. Conglomerate bodies in particular, can be correlated throughout these thrust-top basins (Fig. 5), reflecting the regional scale of the processes that control the formation or destruction of accommodation space along the front of the southern Apennines (Palladino et al. 2011). In all thrust-top basins a basal alluvial fan-delta conglomerate is followed by a generalised drowning documented by Early Pliocene (MPL4a) clays containing G. puncticulata (stage B in figure 9), reflecting relative sea-level rise and narrowing of the emerged areas (Ciarcia et al. 2003; Palladino 2011).

Around the end of biozone MPL4a, coeval to buttressing in the Ofanto basin (stages B and C, in figure 9), syn-sedimentary contractional deformation is also recorded in the Acerenza and Ariano Irpino areas. Relative sea-level drop and emersion of approximately NW-SE trending ridges of pre-Pliocene substratum is 
accompanied by deposition of a younger generation of fan-delta conglomerate equivalent to the II generation of conglomerate (Cairano-Calitri, Figs. 3, 5) of the present study. A new transgression above this latter conglomerate is recorded at a regional scale by the deposition of G. crassaformis mudstones (Fig. 5) accompanied by renewed compression along the frontal thrusts of the chain (Palladino 2011). This interval corresponds to the transition between stages C-D of the Ofanto basin evolution (Fig. 9), occurring before a period of quiescence in the late Pliocene (Ciarcia et al. 2003). The last part of the Ofanto basin infill, formed by G. inflata mudstones and the overlying conglomerate (Fig. 5) is not represented in the Ariano Irpino or Acerenza sectors. In the Ofanto basin these Late Pliocene-?Pleistocene deposits record large wavelength NE directed folding related to the contractional deformation of the Apulian carbonates (Fig. 8). This latter tectonic event may not be recorded in the Ariano and Acerenza areas, because of the lack of deposits of suitable age (Ariano) or because the front of the Apulian thrusts is several tens of kilometres to the west (hinterlandwards) of the front of the Apennine chain (Acerenza) (Fig. 2).

Approximately $100 \mathrm{~km}$ south of the Ofanto basin, the S. Arcangelo basin (Fig. 1) constitutes an analogous but younger thrust-top basin of the southern Apennines (Hyppolite et al. 1994; Benvenuti et al. 2006; Ascione et al. 2011). According to Calabrò et al. (2002) this Late Pliocene-Pleistocene basin evolved in a similar way as the Ofanto basin, during buttressing of the Southern Apennines Allochthonous against pre-existing NW-SE normal faults in the Apulian foreland. The main phase of buttressing and back-thrusting in this basin is Early Pleistocene (Calabrò et al. 2002; Benvenuti et al. 2006), in agreement with a southwards younging of tectonic deformation along the southern Apennine orogen (Vezzani et al. 2010). Although 
459 for the S. Arcangelo basin the age of the normal faults is not constrained, the

460 similarity in the mechanisms of formation highlights the role of early-formed structures in the foreland unit in conditioning the geometry of the frontal parts of orogenic wedges.

\section{CONCLUSIONS}

\section{OROGENIC NORMAL FAULTS}

The existence of large syn-orogenic normal faults (or early-orogenic, in De Paola et al. 2006), which form foreland-wards of the advancing thrust fronts, is well documented in the Italian Apennines (Mazzoli, 1994; Tavarnelli \& Peacock 1999; Calamita et al. 1998, 2009; Scisciani et al. 2001, 2002; Billi \& Salvini 2003; Butler et al. 2006; De Paola et al. 2006) and in other orogenic belts (Martínez et al. 1989; Berástegui et al. 1998; Hayman \& Kidd 2002; Séjournée \& Malo 2007; Sieniawska et al. 2010; Casini et al. 2011). Their origin is generally attributed to: a) flexure of the foreland plate due to the load of the advancing thrust system or due to the pull of the down-going slab (Royden 1993), or b) to outer-arc extension in the hinge of the subducting plate (Doglioni 1995). These two mechanisms are not mutually exclusive; instead, they can complement and reinforce each other producing higher amounts of extensional strain. We believe that a specific analysis of the factors that determine the formation of these normal faults, their orientation, the size and location with respect to the subducting lithosphere hinge could offer a significant contribution to the comprehension of lithospheric subduction and its roll-back process. 
485 Two principal and consecutive stages, marked by different tectonic processes, characterise the evolution of the Ofanto basin. The first stage, lasting throughout the Early Pliocene (post 5.33 - $3.57 \mathrm{Ma}$ ) and possibly extending into the lowermost part of the Late Pliocene, is the main translation of the SAA over the Apulian carbonate platform, which behaved as the inactive footwall, passively influencing the emplacement of the Southern Apennine Allochthonous with its preexisting structures (Fig. 9 A-C). The main tectonic process resulting from this interaction is the buttressing and thickening of the Allochthonous against the escarpment of the normal fault in the Apulian carbonates and the development of the Ofanto syncline. In a later stage, almost certainly Early Pleistocene in age, the footwall of the SAA, which is formed by Apulian carbonates, became actively involved in the shortening and developed NW-SE trending reverse faults that cut through the basal thrust of the SAA (Figs. 7, 8, 9E). Although thrust displacement is modest within the Apulian carbonates, the overall structural relief caused by thrusting and the associated folding is significant (Fig. 6). The net result of this stage of tectonic activity is the eastwards tilting of the Ofanto syncline and broad NW-SE folding of the Late Pliocene-?Early Pleistocene conglomerate in the western termination of the basin (Fig. 3).

Our interpretation implies a significantly lower amount of shortening of the Apulian Carbonates than in previous interpretations (e.g. Hyppolite et al. 1994), favouring a thick-skinned mode of deformation (Shiner et al. 2004; Scrocca et al. 2005) for the last evolutionary stage of the Southern Apennines. More generally, our study remarks the importance of early-orogenic extensional faults, which form 
ahead of the leading edge of accretionary wedges, in controlling the tectonic

geometry at the front of the orogen.

\section{ACKNOWLEDGEMENTS}

This is a contribution of the Group of Dynamics of the Lithosphere (GDL) supported by the projects: TopoMed CGL2008e03474-E/BTE, ESF-Eurocores 07TOPOEUROPE-FP006, and Consolider-Ingenio 2010 Topo-Iberia (CSD2006e00041). E. Casciello is supported by a JAEDOC project in the frame of the FSE 2007-2013 Program. The authors would like to thank W. Paltrinieri for providing the studied seismic lines and for constructive discussions. We are also grateful to three anonymous reviewers and Subject Editor Erdin Bozkurt.

\section{REFERENCES}

Ascione, S., Ciarcia, S., Di Donato, V., Mazzoli, S. \& Vitale, S. 2011. The Pliocene-Quaternary wedge-top basins of southern Italy: an expression of propagating lateral slab tear beneath the Apennines. Basin Research, 23, 1-19, doi: 10.1111/j.1365-2117.2011.00534.x

Berástegui, X., Banks, C., Puig, C., Taberner, C., Waltham, D. \& Fernández, M. 1998. Lateral diapiric emplacement of Triassic evaporites at the southern margin of the Guadalquivir Basin, Spain. In: Cenozoic Foreland Basins of Western Europe. A. Mascle, C. Puigdefàbregas, H. P. Luterbacher and M. Fernàndez. Geological Society, London, Special Publications, 134, 49-68.

Benvenuti, M., Bonini, M., Moratti, G., Sani, F., 2006. Tectonosedimentary evolution of the PlioPleistocene Sant'Arcangelo Basin (southern Apennines, Italy). In: Moratti, G., Chalouan, A. (Eds.), Tectonics of the Western Mediterranean and North Africa. Geological Society, London, Special Publication, 262, 289-322.

Bertotti, G., Picotti, V., Chilovi, C., Fantoni, R., Merlini, S. \& Mosconi, A. 2001. Neogene to Quaternary sedimentary basins in the south Adriatic (Central Mediterranean): foredeeps and lithospheric buckling. Tectonics, 20, 771-787.

BILLI, A. \& SALVINI, F. 2003. Development of systematic Joints in response to flexure-related fibre stress in flexed foreland plates: the Apulian forebulge case history, Italy. Journal of Geodynamics, 36, 523-536.

Boccaletti, M. \& Guazzone, G. 1974. Remanant arcs and marginal basins in the Cainozoic development of the Mediterranean. Nature, 252, 18-21.

Bonadonna, F.P., Brocchini, D., Laurenzi, M.A., Principe, C. \& Ferrara, G. 1998. Stratigraphical and chronological correlations between Monte Vulture volcanics and sedimentary deposits of the Venosa basin. Quaternary International, 47, 87-96.

Bonardi, G., Ciarcia, S., Di Nocera, S., Matano, F., Sgrosso, I. \& Torre, M. 2009. Carta delle principali Unità Cinematiche dell'Appennino meridionale. Italian Journal of Geoscience (Bollettino della Società Geologica Italiana), 128, 47-60. 
Butler, R.W.H., TAVARnElLI, E., Grasso, M. 2006. Structural inheritance in mountain belts: An Alpine-Apennine perspective. Journal of Structural Geology, 28, 1893-1908, doi: 10.1016/j.jsg.2006.09.006.

BUTLER, R.W.H. 2009. Relationships between the Apennine thrust belt, foredeep and foreland revealed by marine seismic data, offshore Calabria. Italian Journal of Geoscience (Bollettino della Società Geologica Italiana), 128 (2), 269-278.

Calabrò, R.A., Feltre, L. \& Perrotti, C. 2002. Structural features of S. Arcangelo piggyback basin (Southern Apennines-Italy) from seismic data and analogue modelling. Bollettino Società Geologica Italiana, Volume Speciale 1, 333-341.

Calamita, F., Esestime, P., Paltrinieri, W., Scisciani, V. \& Tavarnelli, E. 2009. Structural inheritance of pre- and syn-orogenic normal faults on the arcuate geometry of PlioceneQuaternary thrusts: examples from the Central and Southern Apennine Chain. Italian Journal of Geoscience (Bollettino della Società Geologica Italiana), 128, 381-394.

Calamita, F., Satolli, S., Scisciani, V., Esestime, P. \& Pace, P. 2010. Contrasting styles of fault reactivation in curved orogenic belts: Examples from the Central Apennines (Italy). Geological Society of America Bulletin, doi: 10.1130/B30276.1

Calamita, F., Pizzi, A., Ridolfi, M., Rusciadelli, G., \& Scisciani, V. 1998. II buttressing delle faglie sinsedimentarie pre-thrusting sulla strutturazione neogenica della catena appenninica: l'esempio della M.gna dei Fiori (Appennino Centrale esterno). Italian Journal of Geoscience (Bollettino della Società Geologica Italiana), 117, 725-745.

Casciello, E. \& Cesarano, M. 2000. Geological cross sections through the upper Ofanto Valleyrelationship between tectonics and deposition in a piggy-back basin. Memorie Società Geologica Italiana, 55, 157-163.

Casciello, E., Cesarano, M. \& Pappone, G. 2006a. Stratigraphic and structural setting of the Salerno area. Rendiconti della Società Geologica Italiana, 2, 112-113.

Casciello, E., Cesarano, M. \& Pappone, G. 2006b. Extensional detachment faulting on the Tyrrhenian margin of the southern Apennines contractional belt (Italy). Journal of the Geological Society, 163, 617-629.

Casero, P., Roure, F., Endignoux, L., Moretti, I., Muller, C., Sage L. \& Vially, R. 1988. Neogene geodynamic evolution of the Southern Apennines. Bollettino della Società Geologica Italiana, 41, 109-120.

Casini, G., Gillespie, P., Vergés, J., Romaire, I., Fernández, N., Casciello, E., Saura, E., Homke, S., EMBRY, J.-C., HUNT, D.W. 2011. Sub-seismic fractures in foreland fold and thrust belts: Insight from the Lurestan Province, Zagros Mountains, Iran. Petroleum Geoscience 17, 263282.

Cello, G., Martini, N., Paltrinieri, W. \& Tortorici, L. 1989. Structural styles in the frontal zones of the Southern Apennines, Italy: an example from the Molise district. Tectonics, 7, 753-768.

Cello, G. \& MAzzoli, S. 1999. Apennine tectonics in southern Italy: a review. Journal of Geodynamics, 27, 191-211.

Ciarcia, S., Di Nocera, S., Matano, F. \& Torre, M. 2003. Evoluzione tettono-sedimentaria e paleogeografia dei depocentri «wedge-top» nell'ambito del «foreland basin system» pliocenico dell'Appennino meridionale (settore Irpino-Dauno). Bollettino Società Geologica Italiana, 122, 117-137.

Couzens-Shultz, B.A., VendeVille, B.C. \& WiltschKo, D.V. 2003. Duplex style and triangle zone formation: insights from physical modeling. Journal of Structural Geology, 25, 1623-1644. 
D'Argenio, B., Pescatore, T. \& Scandone, P. 1975. Structural pattern of the Campania- Lucania Apennines. In "Structural Model of Italy", C.N.R., Quaderni Ricerca Scientifica, 90, 313- 327.

De Paola, N., Mirabella, F., Barchi, M.R. \& Burchielli, F. 2006. Early orogenic normal faults and their reactivation during thrust belt evolution: The Gubbio Fault case study, Umbria-Marche Apennines (Italy). Journal of Structural Geology, 28, 1948-1957

Di Nocera, S., Matano, F., Pescatore, T.S., Pinto, F., Quarantiello, R., Senatore, M. R. \& TORRE M. 2006. Schema geologico del transetto Monti Picentini orientali-Monti della Daunia meridionali: unità stratigrafiche ed evoluzione tettonica del settore esterno dell'Appennino meridionale. Italian Journal of Geoscience (Bollettino della Società Geologica Italiana), 125, 3958.

Doglioni, C. Mongelli, F. \& PieRi, P. 1994. The Puglia uplift (SE Italy): an anomaly in the foreland of the Apennine subduction due to buckling of a thick continental lithosphere. Tectonics, 13, 1309-1321.

DogliONI, C. 1995. Geological remarks on the relationships between extension and convergent geodynamic settings. Tectonophysics, 252, 253-267.

EDWARDS, M. \& GRASEMANN, B. 2009. Mediterranean snapshots of accelerated slab retreat; subduction instability in stalled continental collision. In: VAN HINSBERGEN, D., EDWARDS, M., Govers, R. (eds.): Collision and collapse at the Africa-Arabia-Eurasia subduction zone. Geological Society, London, Special Publications, 311, 155-192.

ERICKSON, S.G. 1995. Mechanics of triangle zones and passive-roof duplexes: implications of finite-element models. Tectonophysics, 245, 1-11.

ESESTIME, P. 2009. 3D Structural analysis and Pliocene-Quaternary evolution of the buried Apulian chain in the Southern Apennines (Italy). Ph.D. Thesis, School of Advanced Studies, "G.d'Annunzio" University of Chieti-Pescara.

Finetti, L.R., Calamita, F., Crescenti, U., Del Ben, A., Forlin, E., Pipan, M., Prizzon, A., RusciadelLI, G. \& SCISCIANI, V. 2005. Crustal geologic section across Central Italy from Corsica Basin to the Adriatic Sea, based on geological and crop seismic data. In: Finetti I. (Ed.) CROP, Deep Seismic Exploration of the Central Mediterranean Region. Chapter 9, 159-195.

GiannANDREA, P. 2003. Analisi sedimentologica del Sintema di Monte Sirico (parte alta della successione del Bacino dell'Ofanto. Il Quaternario, 16, 269-277.

Giannandrea, P., Marino, M., Romeo, M., Schiattarella, M., 2009. Carta geologica del settore orientale del bacino dell'Ofanto, scala 1:25.000, L.A.C., Firenze

GolonkA, J. 2004. Plate tectonic evolution of the southern margin of Eurasia in the Mesozoic and Cenozoic. Tectonophysics, 381, 235-273.

HAYMAN, N.W. \& KIDD, W.S.F. 2002. Reactivation of prethrusting, synconvergence normal faults as ramps within the Ordovician Champlain-Taconic thrust system. Geological Society of America Bulletin, 114, 476-489. doi: 10.1130/0016-7606(2002)114<0476:ROPSNF>2.0.CO;2

Hippolyte, J.C., Angelier, J., Roure, F. \& CAsero, P. 1994. Piggyback basin development and thrust belt evolution: Structural and palaeostress analyses of Plio-Quaternary basins in the Southern Apennines. Journal of Structural Geology, 16, 159 - 173.

IPPolito, F., ORTOlAnI, F. \& Russo, M. 1973. Struttura marginale tirrenica dell'Appennino Campano: reinterpretazione di dati di antiche ricerche di idrocarburi. Memorie Società Geologica Italiana, XII, 227-250. 
Lustrino, M., Duggen, S. \& Rosenberg, C.L. 2011. The Central Western Mediterranean: Anomalous igneous activity in an anomalous collisional tectonic setting. Earth-Science Reviews, 104, 1-40.

Kastens, K., Mascle, J. \& ODP Leg 107 Scientific StafF. 1988. ODP Leg 107 in the Tyrrhenian sea: insights into passive margin and back-arc basin evolution. Geological Society of America Bulletin, 100, 1140-1156.

MALINVERNo, A. \& RYAN, W.B.F. 1986. Extension in the Tyrrhenian Sea and shortening in the Apennines as result of arc migration driven by sinking of the lithosphere. Tectonics, 5, 227245.

MARIOtTI, G. \& Doglioni, C., 2000. The dip of the foreland monocline in the Alps and Apennines. Earth and Planetary Science Letters, 181, 191-202.

Martinez, A., Vergés, J., Clavell, E. \& Kennedy, J. 1989. Stratigraphic framework of the thrust geometry and structural Inversion in the southeastern Pyrenees: La Garrotxa area. Geodinamica Acta, 3 (3), 185-194.

MAZzOLI, S. 1994. Early deformation features in synorogenic Messinian sediments of the northern Marchean Apennines (Italy). Annales Tectonicae, 8, 134-147.

Mazzoli, S., Barkham, S., Cello, G., Gambini, R., Mattioni, L, Shiner P. \& Tondi, E. 2001. Reconstruction of continental margin architecture deformed by contraction of the Lagonegro Basin, southern Apennines, Italy. Journal of the Geological Society, London, 158, 309-319

Mostardini, F. \& Merlini, S. 1986. Appennino Centro-Meridionale: sezioni geologiche e proposta di modello strutturale. Memorie della Società Geologica Italiana, 35, 177-202.

Nicolal, C. \& GAMBINI, R. 2007. Structural architecture of the Adria platform-and-basin system. Italian Journal of Geoscience (Bollettino Società Geologica Italiana), 7, 21-37.

ORtolanI, F. 1974. Faglia trascorrente pliocenica nell'Appennino Campano. Bollettino Società Geologica Italiana, 93, 609-622.

PAlladino, G. 2011. Tectonic and eustatic controls on Pliocene accommodation space along the southern Apennine thrust-belt (Basilicata, southern Italy). Basin Research, doi: 10.1111/j.13652117.2011.00503.x

Pappone, G. \& Ferranti, L. 1995. Thrust tectonics in the Picentini mountains, Southern Apennines, Italy. Tectonophysics, 252, 331-348.

Pappone, G., Casciello, E., Cesarano, M., D’Argenio, B. \& Conforti, A. 2009. Note illustrative della Carta Geologica d'Italia alla scala 1:50.000, foglio 467 SALERNO. Servizio Geologico d'Italia-ISPRA, Rome, 2009.

PATACCA, E. \& ScANDONE, P. 2007. Constraints on the interpretation of the CROP-04 seismic line derived from Plio-Pleistocene foredeep and thrust-sheet-top deposits (Southern Apennines, Italy). Italian Journal of Geoscience (Bollettino della Società Geologica Italiana), Special Issue, 7, 241-256.

Pescatore, T. 1988. La sedimentazione miocenica nell'Appennino Campano Lucano. Memorie della Società Geologica Italiana, 41, 37-46.

Schettino, A. \& TuRco, E. 2010. Tectonic history of the western Tethys since the Late Triassic. Geological Society of America Bulletin, doi: 10.1130/B30064.1

Schiattarella, M., Beneduce, P., Di Leo, P., Giano S.I., Giannandrea, P. \& Principe, C. 2005. Assetto strutturale ed evoluzione morfotettonica quaternaria del vulcano del Monte Vulture (Appennino lucano). Italian Journal of Geoscience (Bollettino della Società Geologica Italiana), 
$2005,124,543-562$.

Scisciani, V., Calamita, F., Tavarnelli, E., Rusciadelli, G., Ori, G.G. \& Paltrinieri, W. 2001. Foreland-dipping normal faults in the inner edges of syn-orogenic basins: A case from the Central Apennines, Italy. Tectonophysics, 330, 211-224.

Scisciani, V., TAVARnelli, E. \& CALAmita, F. 2002. The interaction of extensional and contractional deformations in the outer zones of the Central Apennines, Italy. Journal of Structural Geology, 24, 1647-1658.

Scrocca, D., Carminati, E. \& Doglioni, C. 2005. Deep structure of the Southern Apennines, Italy: Thin-skinned or thick-skinned? Tectonics, 24, TC3005, doi:10.1029/2004TC001634, 2005

SÉJOURNÉE, S. \& MALO, M. 2007. Pre-, syn-, and post imbrication deformation of carbonate slices along the southern Quebec Appalachian front - Implications for hydrocarbon exploration. Canadian Journal of Earth Sciences, 44 (4), 543-564.

Sella, M., TuRci C. \& Riva, A. 1990. Petroleum geology of the "Fossa Bradanica" (foredeep of the Southern Apennine thrust belt), In: J. Brooks (Ed.) Classic Petroleum Provinces. Geological Society, London, Special Publications, 50, 369-378.

Shiner, P., Beccacini, A. \& Mazzoli, S. 2004. Thin-skinned versus thick-skinned structural models for Apulian carbonate reservoirs: constraints from the Val d'Agri Fields, S Apennines, Italy. Marine and Petroleum Geology, 21, 805-827.

Sieniawska, I., Aleksandrowski, P., Rauch, M. \& Koyi, H. 2010. Control of synorogenic sedimentation on back and out-of-sequence thrusting: Insights from analog modeling of an orogenic front (Outer Carpathians, southern Poland). Tectonics, 29, TC6012, doi:10.1029/2009TC002623

Tavarnelli, E. \& PeAcock, D. 1999. From extension to contraction in synorogenic foredeep basins: the Contessa section, Umbria-Marche Apeninnes, Italy. Terra Nova 11, 55-60.

Vezzani , L., Festa, A. \& Ghisetti, F.C. 2010. Geology and Tectonic Evolution of the CentralSouthern Apennines, Italy. Geological Society of America Special Paper, 469, doi: 10.1130/2010.2469.

\section{FIGURE CAPTIONS}

Figure 1. Geological map of the Southern Apennines showing the main lithotectonic assemblages composing the belt and the location of the Ofanto basin.

Figure 2. Schematic regional cross section of the Southern Apennines. Trace in Figure 1 (redrawn from Mostardini \& Merlini 1988).

Figure 3. Geological map of the Ofanto basin showing the main structural features, results of biostratigraphic analyses and traces of seismic lines of figure 
6. Biostratigraphic data on calcareous nannoplankton (square symbols) is according to Hippolyte et al. 1994.

Figure 4. Schematic logs of exploration wells in the studied area. Location of wells, of the studied seismic grid (dashed lines) and of the line drawings in figure 6 (solid lines), is shown in A.

Figure 5. Lithostratigraphic chart of the units exposed along the northern margin of the Ofanto syncline, based on field data and original biostratigraphic analyses (Figure 3). The columns on the right show the unconformity-bounded units recognised in the eastern half of the Ofanto basin, and the unconformity-bounded units recognised in the contiguous basins of Acerenza (1 - Palladino et al. 2011) and Ariano Irpino (2 - Ciarcia et al. 2003); square patterns indicate the main conglomerate bodies.

Figure 6. Line drawings of selected seismic profiles crossing the Ofanto basin. Location is shown in figure 3.

Figure 7. Depth map in TWT of the top Apulian carbonates in the Ofanto basin area.

Figure 8. 3D model of the top Apulian surface underlying the Ofanto basin. The model was constructed in $\mathrm{GoCad}^{\circledR}$, using the line drawings shown in figure 6 , and is sliced in a direction parallel to the trend of the Ofanto syncline (E-W) in order to highlight the eastward slope of the top Apulian carbonates in the hangingwall block of the normal fault. Refer to figure 7 for a map view.

Figure 9. Cartoon illustrating the tectono-sedimentary evolution of the Ofanto thrust-top basin. Vertical distance is not to scale, horizontal scale is approximate. In stage $\mathrm{E}$ the direction of tectonic transport is out of the section plane. 


\section{SW}

Picentini Mts.

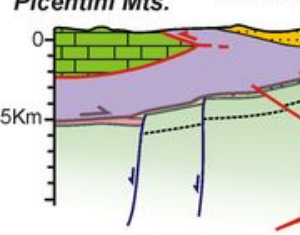

Siliciclastic deposits
Pleistocene
Pliocene,
a) Messinian evaporites
Pliocene piggy-back deposits

Allocthonous Units (SAA)

Apennine Carbonate Platform

Early Triassic-Miocene

Undifferentiated Basinal Units (Sicilide,Sannio and Lagonegro) and siliciclastic deposits Early Triassic-Miocene
Apulian Carbonate Platform Late Triassic-Miocene

Basal thrust of the Southern Apennine Allochtonous 


\section{M.FORCUSO 2}

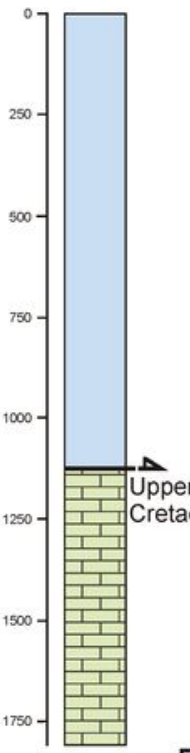

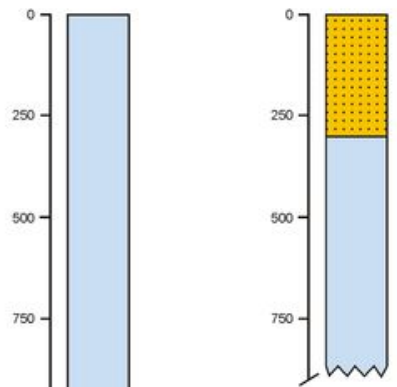
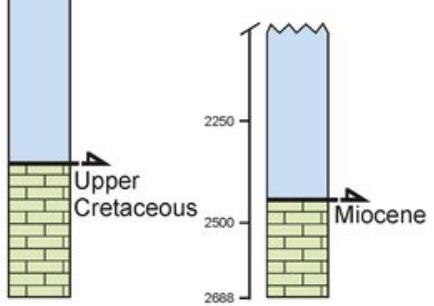
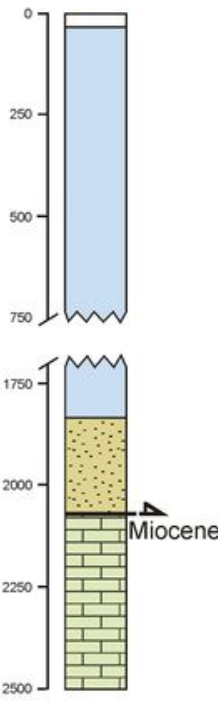

2500

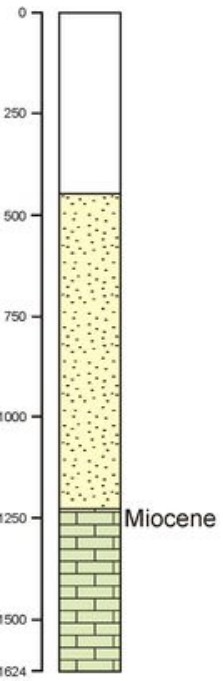

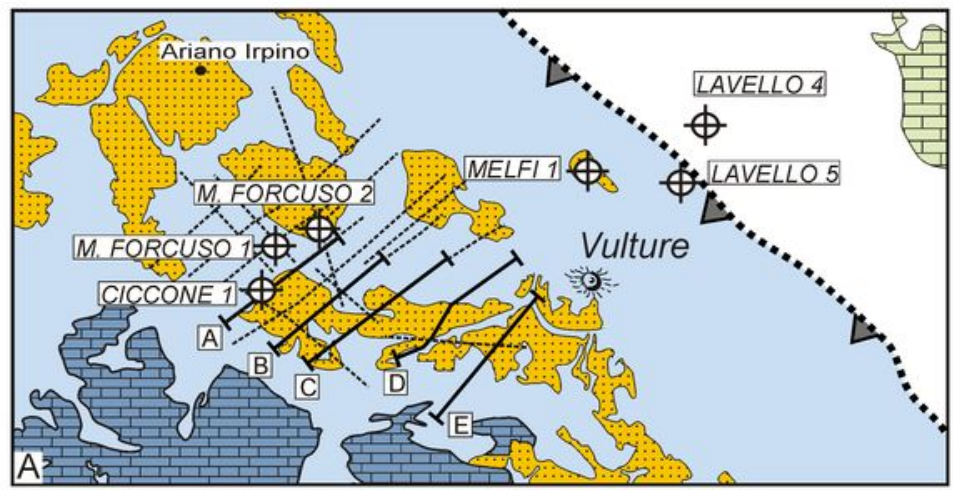

Quaternary deposits

Pliocene thrust-top deposits

Early Pliocene

siliciclastic deposits

Early Pliocene

calcareous breccias

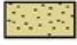

Late Pliocene

siliciclastic deposits
Lagonegro basinal units and related siliciclastic deposits

Apulian Carbonate Platform
Basal thrust of the Southern Apennine Allochthonous

...... Studied seismic grid $\neg$ Line drawings of figure 6 


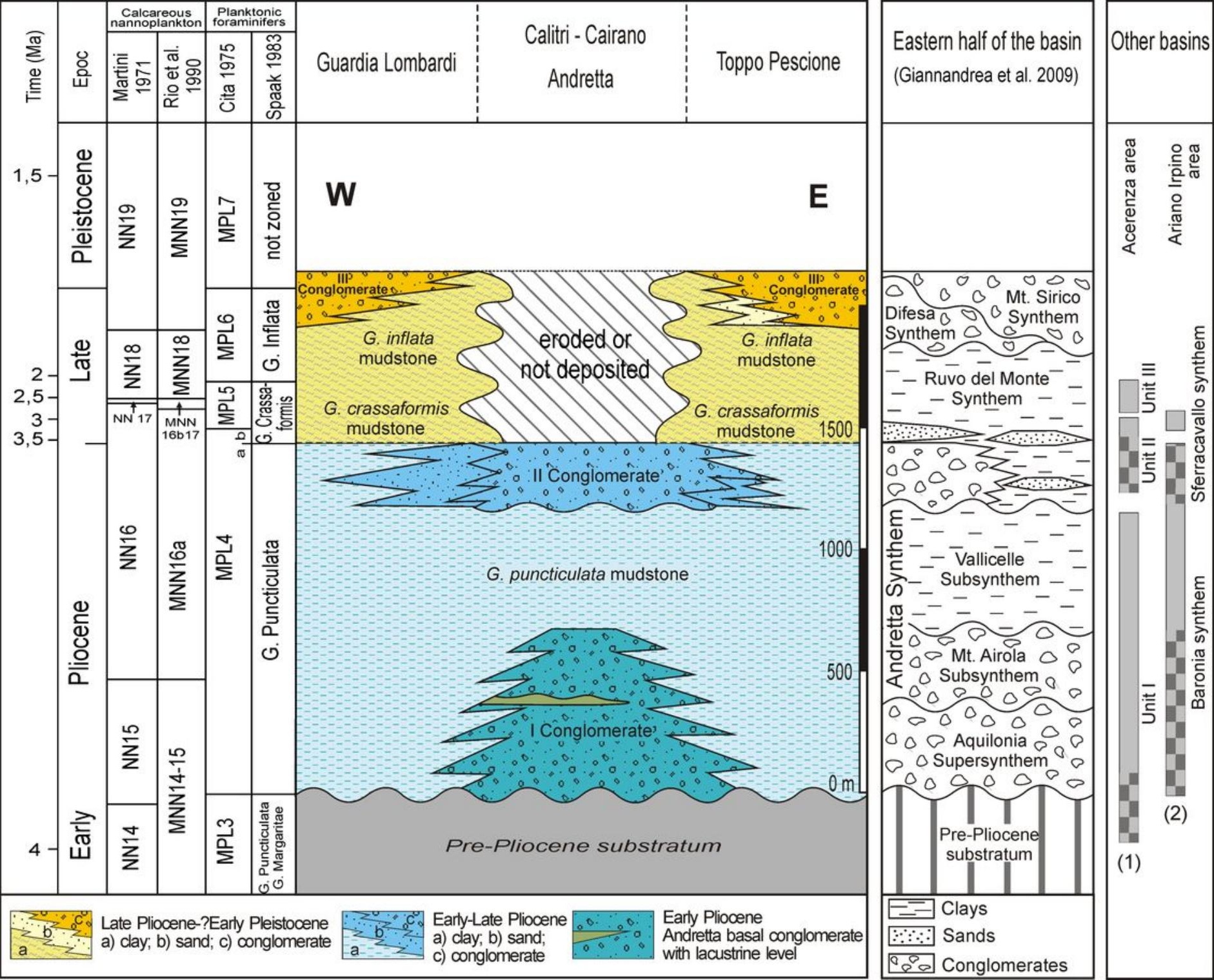




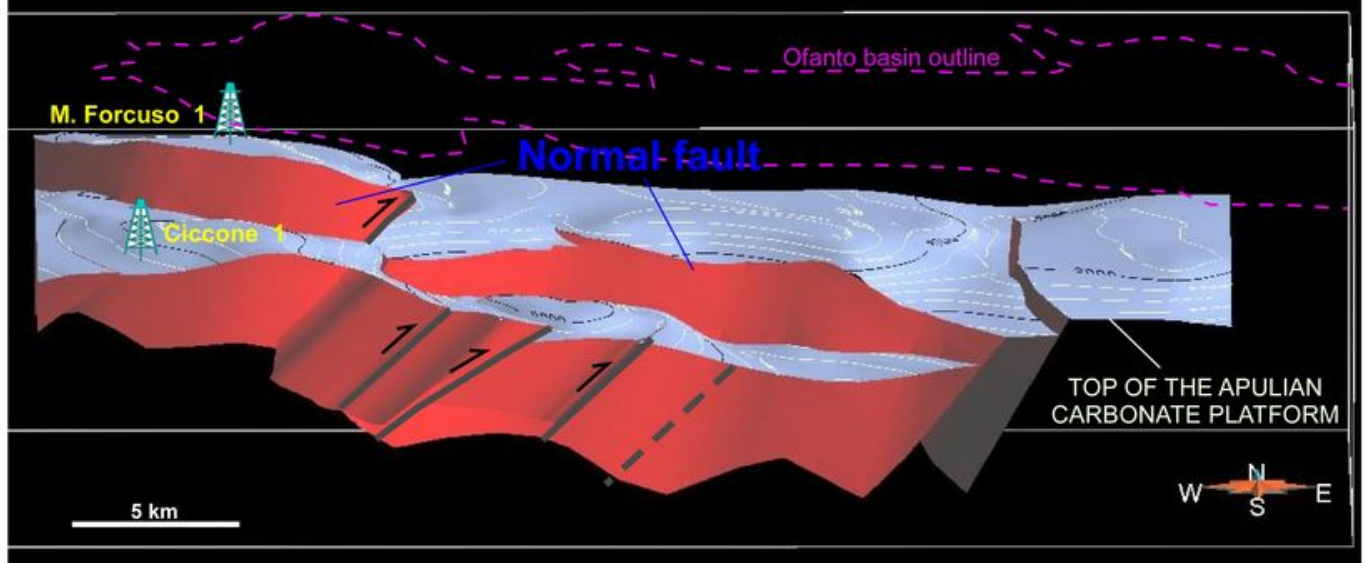

Figure 8. 3D model of the top Apulian surface underlying the Ofanto basin. The model was constructed in GoCad, using the line drawings shown in figure 6, and is sliced in a direction parallel to the trend of the Ofanto syncline (E-W) in order to highlight the eastward slope of the top Apulian carbonates in the hangingwall of the normal fault. Refer to figure 7 for a map view. 


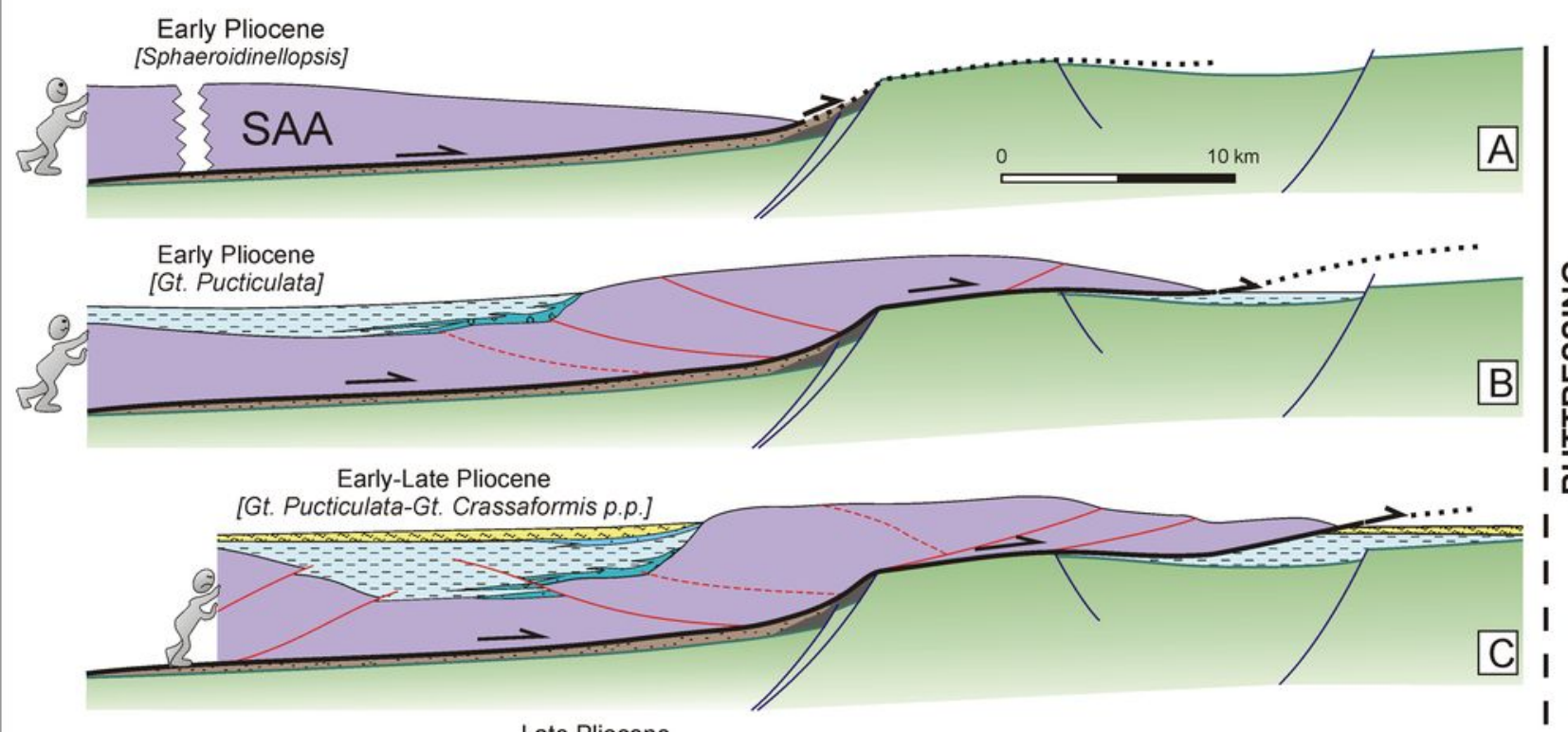

\section{Early Pliocene}

[Sphaeroidinellopsis]

Early Pliocene

[Gt. Pucticulata]
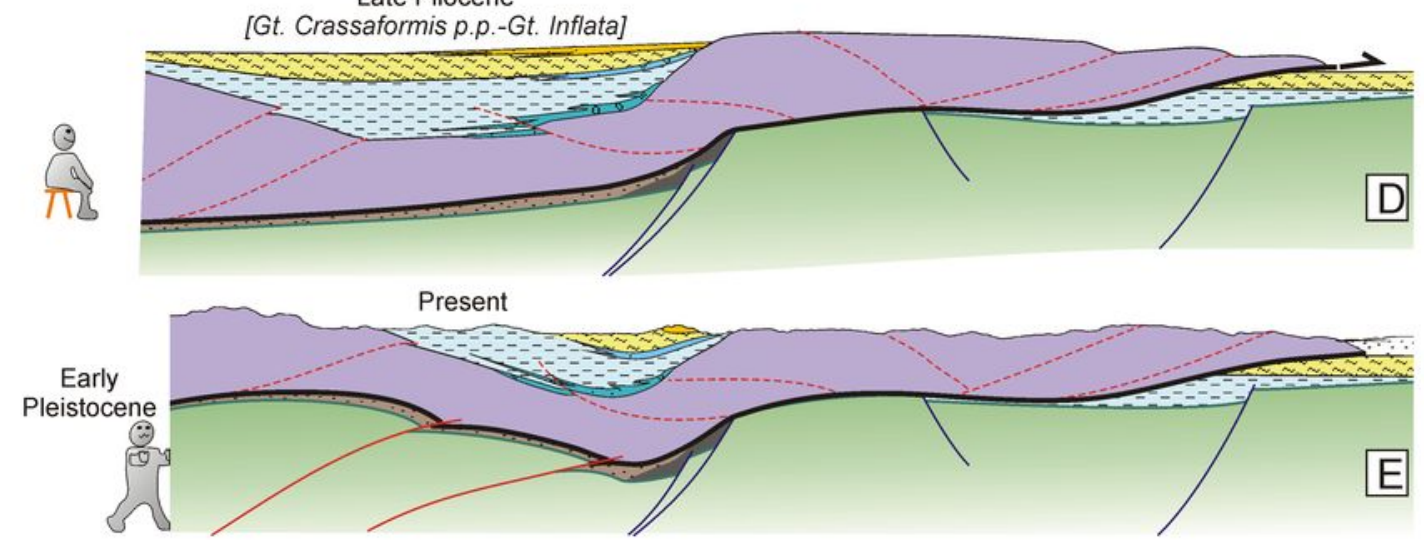

Pleistocene

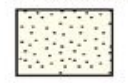

Late Pliocene-?Early Pleistocene (a)

U. a deposits containing Gt.crassaformis,

$\therefore \therefore$ Gt. inflata. (a) III conglomerate

"Toppo Pescione"

\section{Early Pliocene}

U. - a deposits containing Gt. puncticulata.

(a) II conglomerate

"Cairano-Calitri"
Early Pliocene

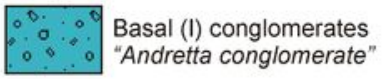

Early Pliocene

$\because \because \because$ deposits containing

Sphaeroidinellopsis

Late Miocene-?Early Pliocene

Calcareous Breccias
Southern Apennine Allochthonous (SAA)

Apulian carbonate Platform

$\because$ Allochthonous basal thrust à a) future trajectory

Thrust $\quad$ Normal Fault 